\title{
Trithiols and their Arsenic Compounds for Potential Use in Diagnostic and Therapeutic Radiopharmaceuticals
}

\author{
Anthony J. DeGraffenreid ${ }^{1}$, Yutian Feng ${ }^{1}$, Charles L. Barnes ${ }^{1}$, Alan R. Ketring ${ }^{2}$, Cathy S. \\ Cutler $^{2}$, Silvia S. Jurisson ${ }^{1,2^{*}}$ \\ ${ }^{1}$ Department of Chemistry, ${ }^{2}$ Research Reactor Center (MURR), University of Missouri, \\ Columbia 65211
}

\begin{abstract}
Introduction. Arsenic-72 $\left({ }^{72} \mathrm{As} ; 2.49 \mathrm{MeV} \beta^{+}, 26 \mathrm{~h}\right)$ and ${ }^{77} \mathrm{As}\left(0.683 \mathrm{MeV} \beta^{-}, 38.8 \mathrm{~h}\right)$ have nuclear properties useful for positron emission tomography (PET) and radiotherapy applications, respectively. Their half-lives are sufficiently long for targeting tumors with antibodies, as well as peptides. Potential radiopharmaceuticals based on radioarsenic require development of suitable bifunctional chelates for stable conjugation of arsenic to vectors under in vivo conditions at high dilution.

Methods. The thiophilic nature of arsenic led to the synthesis and characterization of a simple trithiol ligand and its arsenic complex, and radiolabeling studies at the no carrier added (NCA) ${ }^{77}$ As level.

Results. ${ }^{1} \mathrm{H}$ - and ${ }^{13} \mathrm{C}-\mathrm{NMR}$ spectroscopy, electrospray ionization mass spectrometry (ESI-MS), and single crystal X-ray diffraction were used to characterize the trithiol ligand and its arsenic(III) complex. Radiotracer studies with no carrier added (NCA) ${ }^{77}$ As resulted in high radiolabeling yields (>96\%) with high in vitro stability.

Conclusions. The high yield and stability of a single $\mathrm{NCA}{ }^{77}$ As trithiol complex indicates this framework is suitable for developing matched pair agents for non-invasive in vivo PET imaging and radiotherapy of tumors with ${ }^{72,77}$ As. This is the first reported chelate developed for NCA radioarsenic and studies are underway for developing a trithiol bifunctional chelate conjugated to a targeting vector, such as a peptide or monoclonal antibody.
\end{abstract}

Running Title: Trithiols and their $\left[{ }^{77 / n a t}\right.$ As $]$ Arsenic Compounds

Key Words: trithiol ligand; arsenic trithiol; no carrier added ${ }^{77}$ As; radiolabeling; crystal structures

Correspondence to: Silvia S. Jurisson, Department of Chemistry, University of Missouri, Columbia, MO 65211, USA; jurissons@ missouri.edu; 573-882-2107; 573-882-2754 (fax) 


\section{Introduction}

Diagnostic imaging and radiotherapy using radiolabeled drugs (radiopharmaceuticals) often involve radiometals such as ${ }^{99 \mathrm{~m}} \mathrm{Tc}$ and ${ }^{90} \mathrm{Y}$, or non-metals such as ${ }^{18} \mathrm{~F}$ and ${ }^{131} \mathrm{I}$. Positron Emission Tomography (PET) has become an important nuclear medicine imaging technique, especially since the approval of 2-deoxy- $\left({ }^{18} \mathrm{~F}\right)$-fluoroglucose $\left({ }^{18} \mathrm{~F}-\mathrm{FDG}\right)$ for imaging metabolism. With the exception of ${ }^{89} \mathrm{Zr}$ (3.27 d) and ${ }^{124} \mathrm{I}(4.18 \mathrm{~d})$, the more commonly used positron emitters $\left({ }^{11} \mathrm{C},{ }^{18} \mathrm{~F}\right.$, ${ }^{64} \mathrm{Cu}$ ) are too short-lived for use in radioimmunoimaging with radiolabeled antibodies, which often take days to localize and clear from non-target tissues [1]. Two radioisotopes of arsenic, ${ }^{72}$ As and ${ }^{77}$ As, have nuclear properties that would make them a true "matched pair" for diagnostic and therapeutic nuclear medicine (Table 1) and potentially useful for radioimmunoimaging and radioimmunotherapy.

Arsenic-72 is a $26 \mathrm{~h}$ positron emitter for which development of a ${ }^{72} \mathrm{Se}^{72} \mathrm{As}$ generator has been reported, potentially leading to portable availability of this PET radionuclide [2-6]. Arsenic-77 is a $38.8 \mathrm{~h}$ beta emitter that is reactor produced through neutron irradiation of enriched ${ }^{76} \mathrm{GeO}_{2}$ followed by beta decay of ${ }^{77} \mathrm{Ge}(11.3 \mathrm{~h})$. The production of radioarsenic using various targets and irradiation methods (proton, neutron, alpha, ${ }^{3} \mathrm{He}$ ) have been described, as have separation methods for radioarsenic including distillation, chromatography, solvent extraction and precipitation, with most methods yielding radioarsenic in the +3 oxidation state [7-13]. At no carrier added (NCA) levels, As(III) readily oxidizes to As(V) within minutes, and thus development of methodologies to reduce $\mathrm{As}(\mathrm{V})$ and utilize NCA radioarsenic as As(III) for radiosyntheses were developed.

\section{Table 1}

The utilization of the water soluble dithiolates, British Anti-Lewisite (BAL), 2,3mercaptosuccinic acid (DMSA), and 2,3-dimercaptopropanesulfonate (DMPS), for chelation therapy for the treatment of arsenic poisoning is well known [15]. However, few, if any, chelators specific for stabilizing NCA radioarsenic for radiopharmaceutical applications have been reported [15]. The thiophilic nature of arsenic to directly label the targeting moiety of interest has been reported for radiolabeling HMPA ( $N$-(2-hydroxypropyl)-methacrylamide) based polymers via free sulfhydryl groups for potential PET imaging, and peptides containing 1 to 4 cysteines to assess the binding affinity of arsenic for thiol containing peptides [16,17]. Only one report by Jennewein et al. used NCA radioarsenic to investigate the in vivo localization of $\mathrm{N}$ succinimidyl $S$-acetylthioacetate (SATA) derivatized Bavituximab ch3G4 (a chimeric $\mathrm{IgG}_{3}$ monoclonal antibody) and Rituximab in prostate tumor bearing rats $[18,19]$.

This study reports the development of a trithiol chelate and its As(III) complex for potential in vivo applications at the no carrier added (NCA) radiotracer level. A trithiol chelate and its arsenic complex were synthesized and fully characterized by ${ }^{1} \mathrm{H}-$ and ${ }^{13} \mathrm{C}-\mathrm{NMR}$, ESI-MS, elemental analysis, and X-ray crystallography. Radiolabeling with $\mathrm{NCA}^{77}$ As was optimized and the 
bicyclic $\left[{ }^{77}\right.$ As]arsenic trithiol complex was shown to be stable in vitro at room temperature over several days.

\section{Experimental}

Materials. CAUTION! Arsenic is highly toxic and should be handled with care. Arsenic trioxide, 1,1,1-tris(hydroxymethyl)propane, mercaptoacetic acid, anhydrous dimethylformamide, pyridine, lithium aluminum hydride, potassium hydroxide, $p$-toluene sulfonyl chloride, ammonium chloride, and potassium thiocyanate were purchased from commercial sources and used as received. Silica gel 60A (Acros Organics), TWEEN® 80 (Sigma Aldrich-St. Louis, MO), silica gel 60A (Fisher Scientific-Pittsburgh, PA), silica gel TLC plates (SelectoScientificSuwanee, GA), and $13 \mathrm{~mm} 0.2 \mu \mathrm{m}$ Nylon Whatman filter discs (GE Healthcare Life SciencesPittsburgh, PA) were used as supplied. All solvents, acids and bases were reagent grade and used without further purification. Only $18 \mathrm{M} \Omega$ water was used.

CAUTION! ${ }^{77}$ As and ${ }^{77} \mathrm{Ge}$ are radioactive and must be handled in laboratories outfitted and approved for work with radioactive materials. Arsenic-77 was prepared by neutron irradiation of $96.2 \%$ or $98.6 \%$ enriched ${ }^{76} \mathrm{GeO}_{2}$ (Trace Sciences International, Richmond Hill, ON, Canada) in a thermal neutron flux of $2.4 \times 10^{14} \mathrm{n} / \mathrm{cm}^{2}-\mathrm{s}$ at the University of Missouri Research Reactor Center (MURR). Arsenic-77: $38.9 \mathrm{~h}, 0.225 \mathrm{MeV} \beta_{\text {avg, }}^{-} 239 \mathrm{keV} \gamma(1.65 \%) ;{ }^{77} \mathrm{Ge}: 11.3 \mathrm{~h}, 1.18$ $\mathrm{MeV} \beta_{\text {avg }}^{-}$, several $\gamma(211 \mathrm{keV}(30 \%), 215.6 \mathrm{keV}$ (27.9\%), and $264.5 \mathrm{keV}(53.3 \%)$.

Physical Measurements. ${ }^{1} \mathrm{H}$ - and ${ }^{13} \mathrm{C}-\mathrm{NMR}$ spectra were obtained in $\mathrm{CDCl}_{3}$ on a Bruker ARX$500 \mathrm{MHz}$ spectrometer using TMS as an internal standard. Electrospray Ionization Mass Spectra (ESI-MS) were obtained on a Thermo Finnigan TSQ7000 triple-quadrupole instrument with an API2 source. Elemental analyses were performed by Atlantic Microlab, Inc. (Norcross, GA). An ORTEC HPGe detector outfitted with Genie multichannel analysis software was used to assay ${ }^{77} \mathrm{Ge}$ and ${ }^{77}$ As liquid samples. Reversed phase HPLC (RP-HPLC) was performed using a Shimadzu Prominence HPLC system equipped with a pump, controller, Prominence UV-Vis detector (model SPD20-AV) set to $254 \mathrm{~nm}$ and coupled to a Beckman $170 \mathrm{NaI}(\mathrm{Tl})$ radioisotope detector. An Eckert \& Ziegler Bioscan AR-2000 Imager using LabLogic Win-Scan imaging scanner software (Version 2.2(11)) was used for scanning radioTLC plates. The gradient system for RP-HPLC using a Thermo Scientific BetaBasic $18(5 \mu \mathrm{m}, 150 \mathrm{~mm}$ x $4.6 \mathrm{~mm})$ column was as follows: 3 minutes at 60/40 ACN/ $\mathrm{H}_{2} \mathrm{O}$ w/ $0.1 \%$ TFA, followed by a linear gradient to 75/25 over $7 \mathrm{~min}$, and to $95 / 5$ over $10 \mathrm{~min}$, all at a flow rate of $1 \mathrm{~mL} / \mathrm{min}$.

X-ray Crystal Structures. Intensity data for compounds 3 and $\mathbf{5}$ were obtained at $-173{ }^{\circ} \mathrm{C}$ on a Bruker SMART CCD Area Detector system using the $\omega$ scan technique with Mo K $\alpha$ radiation from a graphite monochromator. Intensities were corrected for Lorentz and polarization effects. Equivalent reflections were merged, and absorption corrections were made using the multi-scan method. The structures were solved by direct methods with full-matrix least-squares refinement, using the SHELX package [20]. All non-hydrogen atoms were refined with anisotropic thermal 
parameters. The hydrogen atoms were placed at calculated positions and included in the refinement using a riding model, with fixed isotropic $U$. Data were corrected for decay and absorption using the program SADABS [21]. The final difference maps contained no features of chemical significance.

\section{Syntheses}

2-Ethyl-2-((tosyloxy)methyl)propane-1,3-diyl bis(4-methylbenzenesulfonate) $\left[\mathrm{C}_{27} \mathrm{H}_{32} \mathrm{O}_{9} \mathrm{~S}_{3}\right], 2$ [22]. 1,1,1-Tris(hydroxymethyl)propane $(1 ; 10.01 \mathrm{~g}, 74.6 \mathrm{mmol})$ was added to a stirring solution of pyridine $(82.5 \mathrm{~mL})$ at $-5{ }^{\circ} \mathrm{C} . p$-Toluenesulfonyl chloride $(71.04 \mathrm{~g}, 372.6 \mathrm{mmol})$ was then slowly added. After $2 \mathrm{~h}$ the reaction was allowed to slowly come to room temperature and stirred vigorously for approximately 2 days. The reaction progress was followed by silica gel TLC with dichloromethane (DCM) as the mobile phase and visualized using UV, iodine, and $\mathrm{KMnO}_{4}$ (ditosylate, $\mathrm{R}_{\mathrm{f}} \approx 0.2 ; 2, \mathrm{R}_{\mathrm{f}} \approx 0.55 ; p$-toluenesulfonyl chloride, $\mathrm{R}_{\mathrm{f}} \approx 0.95$ ). The reaction was poured into cold $2 \mathrm{M} \mathrm{HCl}(600 \mathrm{~mL})$ to precipitate the crude product. The precipitate was washed with several portions ( $\sim 3 \times 100 \mathrm{~mL})$ of $2 \mathrm{M} \mathrm{HCl}$, followed by dissolution in ethyl acetate (EtOAc) $(200 \mathrm{~mL})$, which was washed with $2 \mathrm{M} \mathrm{HCl}(1 \times 50 \mathrm{~mL})$, saturated sodium bicarbonate $(3 \times 100 \mathrm{~mL})$, and brine $(1 \times 50 \mathrm{~mL})$. The organic phase was dried over anhydrous $\mathrm{MgSO}_{4}$, and taken to dryness under vacuum to give the product as a white solid. Yield: $42.94 \mathrm{~g}, 96.5 \%$. ${ }^{1} \mathrm{H}$

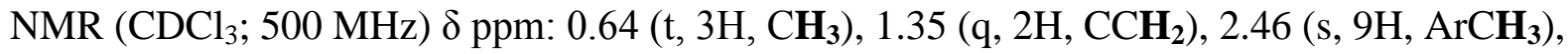
$3.77\left(\mathrm{~s}, 6 \mathrm{H}, \mathrm{OCH}_{2}\right), 7.36(\mathrm{~d}, 6 \mathrm{H}, \mathrm{ArH}), 7.71(\mathrm{~d}, 6 \mathrm{H}, \mathrm{ArH}) .{ }^{13} \mathrm{C} \mathrm{NMR}\left(\mathrm{CDCl}_{3} \mathrm{~d}_{6} ; 125.8 \mathrm{MHz}\right) \delta$ ppm: $6.71\left(\mathrm{CH}_{3}\right), 21.72\left(\mathrm{ArCH}_{3}\right), 21.85\left(\mathrm{CCH}_{2}\right), 42.05(\mathbf{C}), 67.81\left(\mathrm{OCH}_{2}\right), 128.10(\mathrm{ArC})$, 130.23 (ArC), $132.00(\operatorname{ArC})$,$) 145.52 (ArC). ESI-MS ( / 2 / z) 619.30\left(619.08\right.$ calcd for $[\mathrm{M}+\mathrm{Na}]^{+}$ of $\left[\mathrm{C}_{27} \mathrm{H}_{32} \mathrm{O}_{9} \mathrm{~S}_{3}\right]$ ). Elemental Anal. calc'd (found) for $\mathrm{C}_{27} \mathrm{H}_{32} \mathrm{O}_{9} \mathrm{~S}_{3}$ : C, 54.35 (54.40): $\mathrm{H}, 5.41$ (5.47); S, 16.02 (16.12).

1-Thiocyanato-2,2-bis(thiocyanatomethyl)butane $\left[\mathrm{C}_{9} \mathrm{H}_{11} \mathrm{~N}_{3} \mathrm{~S}_{3}\right.$ ], 3 [22]. Intermediate 2 (10.0 g, $16.8 \mathrm{mmol})$ and $\mathrm{KSCN}(21.2 \mathrm{~g}, 218 \mathrm{mmol})$ were added to dry DMF $(50 \mathrm{~mL})$ while vigorously stirring. The reaction mixture was heated to $110{ }^{\circ} \mathrm{C}$ for $13 \mathrm{~h}$, followed by $4 \mathrm{~h}$ at $120^{\circ} \mathrm{C}$, during which time solids formed and the reaction mixture turned dark brown. The reaction was monitored by silica gel TLC with DCM as the mobile phase, and visualized using UV, iodine, and $\mathrm{KMnO}_{4}\left(3 ; \mathrm{R}_{\mathrm{f}} \approx 0.4\right)$. The reaction mixture was poured over crushed ice water $(600 \mathrm{~mL})$ and left in the freezer overnight $\left(-13^{\circ} \mathrm{C}\right)$ to precipitate the crude product $\mathbf{3}$ (1-thiocyanato-2,2bis(thiocyanatomethyl)butane), the trithiocyanate species, $\mathrm{CH}_{3} \mathrm{CH}_{2} \mathrm{C}\left(\mathrm{CH}_{2} \mathrm{SCN}\right)_{3}$. The brown precipitate was isolated by vacuum filtration, washed with deionized water, dissolved in EtOAc $\left(200 \mathrm{~mL}\right.$ ), and dried over anhydrous $\mathrm{Na}_{2} \mathrm{SO}_{4}$. The solvent was removed by vacuum distillation to give brown oily crystalline product. Pure product was obtained by recrystallization from ethyl ether to yield $\mathbf{3}$ as a light yellow crystalline solid. X-ray quality crystals were grown by slow evaporation from chloroform. Yield: $2.6 \mathrm{~g}, 60 \% .{ }^{1} \mathrm{H} \mathrm{NMR}\left(\mathrm{CDCl}_{3} ; 500 \mathrm{MHz}\right) \delta \mathrm{ppm}: 1.01(\mathrm{t}$, $3 \mathrm{H}, \mathrm{CH}_{3}$ ), 1.79 (q, 2H, $\mathrm{CH}_{2}$ ), 3.25 (s, 6H, SCH $\left.\mathbf{H}_{2}\right) .{ }^{13} \mathrm{C} \mathrm{NMR}\left(\mathrm{CDCl}_{3} ; 125.8 \mathrm{MHz}\right) \delta \mathrm{ppm}: 7.85$ $\left(\mathbf{C H}_{3}\right), 26.93\left(\mathrm{CCH}_{2}\right), 38.50\left(\mathrm{SCH}_{2}\right), 44.78(\mathbf{C}), 111.18(\mathrm{SCN})$. ESI-MS $(\mathrm{m} / z) 280.0(280.08$ 
calcd for $[\mathrm{M}+\mathrm{Na}]^{+}$of $\left[\mathrm{C}_{9} \mathrm{H}_{11} \mathrm{~N}_{3} \mathrm{~S}_{3}\right]$ ). Elemental Anal. calc'd (found) for $\mathrm{C}_{9} \mathrm{H}_{11} \mathrm{~N}_{3} \mathrm{~S}_{3}$ : C, 42.00 (42.78); H, 4.31 (4.47); N, 16.33 (15.61); S, 37.37 (36.95).

2-Ethyl-2-(mercaptomethyl)propane-1,3-dithiol $\left[\mathrm{C}_{6} \mathrm{H}_{14} S_{3}\right], 4$ [22]. Compound 3 was converted to the trithiol by reduction with lithium aluminum hydride. Under $\mathrm{N}_{2}$, compound $3(1.0 \mathrm{~g}, 3.9$ mmol) and $\mathrm{LiAlH}_{4}(0.89 \mathrm{~g}, 23 \mathrm{mmol})$ were added to a $50 \mathrm{~mL}$ three necked round bottom flask and cold ethyl ether $(30 \mathrm{~mL})$ was added by syringe after the reaction was cooled to $-5^{\circ} \mathrm{C}$. The reaction was vigorously stirred at $-5^{\circ} \mathrm{C}$ for $3 \mathrm{~h}$ and then brought to room temperature and stirred overnight, during which time grey solids formed. The reaction was quenched by addition of saturated ammonium chloride $(20 \mathrm{~mL})$. Solids were removed by vacuum filtration, and $2 \mathrm{M} \mathrm{HCl}$ $(20 \mathrm{~mL})$ was added to the mother liquor, which was extracted with ethyl ether $(3 \times 50 \mathrm{~mL})$. The organic layers were combined, dried over anhydrous $\mathrm{Na}_{2} \mathrm{SO}_{4}$, filtered, and taken to dryness to yield a light yellow oil, which crystallized upon cooling. Yield: $584 \mathrm{mg}, 82 \% .{ }^{1} \mathrm{H}$ NMR $\left(\mathrm{CDCl}_{3} ; 500 \mathrm{MHz}\right) \delta \mathrm{ppm}: 0.82\left(\mathrm{t}, 3 \mathrm{H}, \mathrm{CH}_{3}\right), 1.18(\mathrm{t}, 3 \mathrm{H}, \mathrm{SH}), 1.46$ (q, 2H, CCH $), 2.58(\mathrm{~d}, 6 \mathrm{H}$, $\left.\mathrm{SCH}_{2}\right) .{ }^{13} \mathrm{C} \mathrm{NMR}\left(\mathrm{CDCl}_{3} ; 125.8 \mathrm{MHz}\right) \delta \mathrm{ppm}: 7.85\left(\mathrm{CH}_{3}\right), 25.10\left(\mathrm{CCH}_{2}\right), 28.80\left(\mathrm{SCH}_{2}\right), 41.66$ (C). ESI-MS $(\mathrm{m} / \mathrm{z}) 181.12$ (181.03 calcd for $[\mathrm{M}-\mathrm{H}]^{-}$of $\left.\left[\mathrm{C}_{6} \mathrm{H}_{14} \mathrm{~S}_{3}\right]\right)$.

4-Ethyl-2,6,7-trithia-1-arsabicyclo[2.2.2] ]octane $\left[C_{6} H_{11} S_{3} A s\right]$, 5. Arsenic trioxide $(0.101 \mathrm{~g}, 0.506$ mmol) was dissolved in ethanol $(95 \%, 20 \mathrm{~mL})$ and ammonium mercaptoacetate $(827.2 \mu \mathrm{L}$ of 5.5 $\mathrm{M}$ aqueous solution, $4.55 \mathrm{mmol}$ ) was added while heating to $50{ }^{\circ} \mathrm{C}$ with stirring. After $60 \mathrm{~min} 4$ $(0.184 \mathrm{~g}, 1.01 \mathrm{mmol})$ was added and stirring continued for $20 \mathrm{~min}$. The reaction mixture was cooled to $-13{ }^{\circ} \mathrm{C}$, and then filtered to remove insoluble material. The filtrate was taken to dryness to yield an off-white precipitate, which was washed with deionized water $(2 \times 15 \mathrm{~mL})$, dissolved in dichloromethane $(10 \mathrm{~mL})$, dried over anhydrous magnesium sulfate, filtered, and taken to dryness to yield light yellow crystals. X-ray quality crystals were grown by slow evaporation from chloroform. Yield: $0.135 \mathrm{~g}, 50.3 \%$. ${ }^{1} \mathrm{H} \mathrm{NMR}\left(\mathrm{CDCl}_{3} ; 500 \mathrm{MHz}\right) \delta \mathrm{ppm}: 0.89$

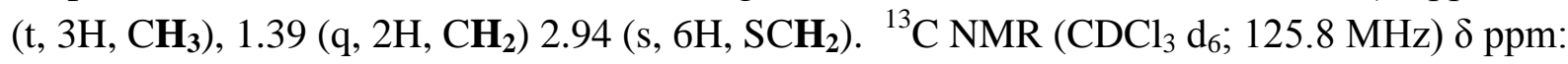
$8.17\left(\mathbf{C H}_{3}\right), 31.29(\mathbf{C}), 31.65\left(\mathrm{SCH}_{2}\right), 37.39\left(\mathrm{CCH}_{2}\right)$. ESI-MS $(\mathrm{m} / z) 254.69$ (254.93 calcd for $[\mathrm{M}+\mathrm{H}]^{+}$of $\left[\mathrm{C}_{6} \mathrm{H}_{11} \mathrm{~S}_{3} \mathrm{As}\right]$ ). Elemental Anal. calc'd (found) for $\mathrm{C}_{6} \mathrm{H}_{11} \mathrm{~S}_{3} \mathrm{As}$ : C, 28.34 (31.42): $\mathrm{H}$, 4.36 (4.70). Note, ${ }^{1} \mathrm{H}-\mathrm{NMR}$ shows residual high vacuum grease at $1.45 \mathrm{ppm}$. RP-HPLC: $\mathrm{t}_{\mathrm{r}}=9.75$ $\min$ (UV detection).

Radiotracer synthesis of no-carrier added ${ }^{77}$ As-(4-ethyl-2,6,7-trithia-1arsabicyclo[2.2.2]octane), $\left[{ }^{77} \boldsymbol{A s}\right] 5$. No carrier added (NCA) ${ }^{77}$ As, as arsenate in methanol, was obtained from MURR. The solvent was removed by gentle heating $\left(50{ }^{\circ} \mathrm{C}\right)$ under air flow, and the $\left[{ }^{77} \mathrm{As}\right]$ arsenate (typically $111-185 \mathrm{MBq}(3-5 \mathrm{mCi})$ ) was taken up in $1.0 \mathrm{~mL}$ of $\mathrm{H}_{2} \mathrm{O}$ yielding a stock solution of $0.111-0.185 \mathrm{MBq} / \mu \mathrm{L}(3-5 \mu \mathrm{Ci} / \mu \mathrm{L})$. The synthesis of $\left[{ }^{77} \mathrm{As}\right] \mathbf{5}$ was carried out by combining aqueous ammonium mercaptoacetate $(500 \mathrm{mM})$, absolute $\mathrm{EtOH}$, and 4 in absolute EtOH $(55 \mathrm{mM})$ in a vial, adding $\left[{ }^{77} \mathrm{As}\right]$ arsenate stock solution, capping and heating in a water bath. The total volume of the reaction was set at $500 \mu \mathrm{L}$ and a solvent mixture of 90/10 EtOH/ $\mathrm{H}_{2} \mathrm{O}$. The ammonium mercaptoacetate (10-25 mM final concentration), [4] (1 $\mu \mathrm{M}-1 \mathrm{mM}$ final concentration), temperature $\left(30-70{ }^{\circ} \mathrm{C}\right)$ and time $(10-60 \mathrm{~min})$ were varied to optimize the 
radiolabeling yield. The radiolabeling yields were determined by silica gel TLC with ethyl ether as the mobile phase. The product, $\left[{ }^{77} \mathrm{As}\right] \mathbf{5}$, migrated with an $\mathrm{R}_{\mathrm{f}}$ of 0.88 while all other species $\left(\left[{ }^{77} \mathrm{As}\right] \text { (mercaptoacetate }\right)_{3},\left[{ }^{77} \mathrm{As}\right]$ arsenate/arsenite) remained at the origin. Optimal reaction conditions were with the monothiol (ammonium mercaptoacetate) concentration at $25 \mathrm{mM}$, the trithiol concentration, (4) at $15 \mu \mathrm{M}$, and the temperature at $60{ }^{\circ} \mathrm{C}$ for $30 \mathrm{~min}$. RP-HPLC: $\mathrm{t}_{\mathrm{r}}=9.88$ $\min (\gamma$ detection).

\section{Results and Discussion}

An underlying theme of nuclear medicine is the radiotracer principle, developed by Georg de Hevesy, which uses very low concentrations (often $\mu \mathrm{M}$ or less depending on half-life) of the radiolabeled molecule (radiopharmaceutical). Radioactivity is easily detected at very low levels and thus attaching a radiolabel to a molecule allows for imaging and/or treatment of disease at concentrations ( $\mu \mathrm{M}$ to $\mathrm{nM}$ or lower) that will not perturb the system. This avoids toxicological effects that may be observed at macroscopic levels often found in pharmaceuticals. No carrier added (NCA) ${ }^{72} \mathrm{As}$ and ${ }^{77} \mathrm{As}$ are two radioisotopes of arsenic that would yield "matched pair" diagnostic and therapeutic radiopharmaceuticals if the chemistry to incorporate them into physiologically stable molecules is developed. A trithiol, 4, was synthesized to evaluate its utility in stabilizing $\mathrm{NCA}{ }^{77} \mathrm{As}$ (III) on complexation.

Trithiol and Arsenic Trithiol Syntheses. Using a modified literature procedure, 2-ethyl-2(mercaptomethyl)propane-1,3-dithiol, 4, was prepared in an overall yield of $48 \%$ (Scheme 1) [22].

\section{Scheme 1}

2-Ethyl-2-((tosyloxy)methyl)propane-1,3-diyl bis(4-methylbenzenesulfonate), 2, was synthesized by reaction of 1,1,1-tris(hydroxymethyl)propane, $\mathbf{1}$, with excess $p$-toluene sulfonyl chloride in pyridine. Reaction of the tritosylate with excess potassium thiocyanate in dry DMF generated 1-thiocyanato-2,2-bis(thiocyanatomethyl)butane, 3. Prolonged heating at high temperature yielded unsatisfactory material and complicated the purification process. Reduction of compound $\mathbf{3}$ with lithium aluminum hydride in diethyl ether yielded 2-ethyl-2-

(mercaptomethyl)propane-1,3-dithiol, 4. All intermediates and the final trithiol were purified using solvent extraction, recrystallization, and/or silica gel column chromatography. The bicycloarsenic (III) compound, 5, precipitated on reaction of arsenic trioxide with the trithiol, $\mathbf{4}$, in the presence of ammonium mercaptoacetate to facilitate the dissolution of $\mathrm{As}_{2} \mathrm{O}_{3}$ in ethanol. The final yield, following purification by solvent extraction, was $50.3 \%$.

All compounds, 2-5, were characterized by elemental analysis, ${ }^{1} \mathrm{H}$ - and ${ }^{13} \mathrm{C}-\mathrm{NMR}$ spectroscopy, and ESI-MS. The molecular ions for all compounds were observed in the ESI-MS spectra at the calculated $m / z$ values. The ${ }^{1} \mathrm{H}-\mathrm{NMR}$ spectrum of the arsenic trithiol compound, $\mathbf{5}$, showed the disappearance of the $-\mathrm{SH}$ protons, a downfield shift of the methylene protons alpha to the coordinated $\mathrm{S}\left(\mathrm{SCH}_{2}\right)$ and the methyl protons $\left(\mathrm{CH}_{3}\right)$ but an upfield shift in the methylene protons 
$\left(\mathrm{CCH}_{2} \mathrm{CH}_{3}\right)$ of the bridgehead ethyl group relative to the free trithiol (Table 2). The ${ }^{13} \mathrm{C}-\mathrm{NMR}$ spectrum of $\mathbf{5}$ showed downfield shifts for all but the bridgehead carbon, which was shifted upfield by 10 ppm (Table 2).

\section{Table 2}

Single Crystal X-ray Structures. Compounds $\mathbf{3}$ and $\mathbf{5}$ were characterized by single crystal X-ray diffraction analysis. Crystal refinement data, bond angles and distances are summarized in Tables 3 and 4. Figure 1 shows the ORTEP structure of $\mathbf{3}$ with its three thiocyanate protecting groups. Bond distances and angles for compound $\mathbf{3}$ were in good agreement with previously reported organic thiocyanates [23-25]. The average C-N distance of $1.1464 \AA$ calculated for $\mathrm{C}(7)-\mathrm{N}(1), \mathrm{C}(8)-\mathrm{N}(3)$, and $\mathrm{C}(9)-\mathrm{N}(3)$ for 3 was within the range (1.139(2) - 1.194(1) $\AA$ ) previously reported for similar compounds [23-25]. The average S-CN bond distance of $1.695 \AA$ for $S(1)-C(7), S(2)-C(8)$, and $S(3)-C(9)$ is slightly longer than previously reported distances of 1.63(1) $\AA$ to 1.693(2) $\AA$ [23-25]. The average $\mathrm{H}_{2} \mathrm{C}-\mathrm{SCN}$ bond distance of $1.831 \AA$ for $\mathrm{S}(1)-\mathrm{C}(4)$, $S(2)-C(5)$, and $S(3)-C(6)$, are slightly longer than previously reported (1.808(6) $\AA$ ) [23-25]. The SCN angles observed lie within the range previously reported for organic thiocyanates of $172.3(1)^{\circ}$ to $197.7(3)^{\circ}[23-25]$.

The arsenic center in $\mathbf{5}$ exhibits the expected trigonal pyramidal geometry on coordination to trithiol 4 (Figure 2). The As-S bond distances observed (2.2348(7) $\AA$ to 2.2379(8) $\AA$ ) fall in the middle of the range (2.2083(6) to 2.2660(10)) of previously reported dithioarsine compounds (i.e., aryl-AsS $\mathrm{S}_{2}$ and $\mathrm{X}-\mathrm{AsS}_{2}$ ) containing 6-membered dithiolates [26-28]. The S-As-S bond angles observed fall at the low end of comparable arsine compounds previously reported $\left(97.27(2)^{\circ}\right.$ to $\left.102.20(5)^{\circ}\right)$, likely due to the constraints of bicyclic ring formation on coordination to As(III) [26-28]. To our knowledge, this is the first structurally characterized monomeric bicyclic trithiaarsine reported.

\section{Table 3}

\section{Table 4}

\section{Figure 1}

\section{Figure 2}

No Carrier Added ${ }^{77}$ As Radiochemistry. The no carrier added (NCA) concentrations of $\left[{ }^{77} \mathrm{As}\right]$ arsenate, the starting material for the radiotracer experiments, are in the $\mathrm{nM}$ and lower range. To ensure that the reaction kinetics are sufficient, all other reactants are in large excess compared to the radionuclide concentration. Therefore minimizing the concentrations of the reactants and ensuring sufficiently fast kinetics for the radiolabeling reaction must be balanced. Of particular importance is minimizing the ligand (trithiol in this case) concentration when biological targeting molecules such as peptides and monoclonal antibodies are incorporated, 
which is the ultimate use of the ligand, since radiolabeled and unlabeled bioconjugate compete for available receptor sites.

The ${ }^{77}$ As was available in oxidation state +5 , as arsenate, so the first step in the radiosynthesis involved reduction to the +3 oxidation state. Ammonium mercaptoacetate $\left(\mathrm{NH}_{4} \mathrm{SR}\right)$ was used as the monothiol to reduce the $\left[{ }^{77} \mathrm{As}\right]$ arsenate to $\left[{ }^{77} \mathrm{As}\right](\mathrm{SR})_{3}$ followed by reaction with trithiol 4 to form $\left[{ }^{77} \mathrm{As}\right] 5$. Optimization included varying the ammonium mercaptoacetate and trithiol, $\mathbf{4}$, concentrations, temperature, and time to achieve high radiolabeling yields under the mildest conditions. The optimization reactions were followed by silica gel radioTLC and contained both monothiol and trithiol. Using monothiol only, the $\left[{ }^{77} \mathrm{As}\right](\mathrm{SR})_{3}$ was observed to oxidize on the TLC plate and streak from the origin toward the solvent front with methanol as the mobile phase. Using trithiol alone for reduction and subsequent complexation did not yield product. Addition of both the monothiol and trithiol at the beginning of the reaction resulted in formation of $\left[{ }^{77} \mathrm{As}\right] 5$. No oxidation/decomposition was observed during radioTLC analysis. Any unreacted arsenic remained at the origin and the product $\left[{ }^{77} \mathrm{As}\right] 5$ migrated to the solvent front with ethyl ether. RP-HPLC was used to verify product formation by comparison to the macroscopic standard with retention times of $9.75 \mathrm{~min}$ and $9.88 \mathrm{~min}$ for the macroscopic and NCA complexes, respectively, by UV and radiodetection (Figure 3).

\section{Figure 3}

Optimization reactions were run in 90/10 ethanol/water to ensure trithiol solubility. The monothiol concentration (1-40 mM), trithiol concentration ([4], $1 \mu \mathrm{M}-5 \mathrm{mM})$, time, and temperature $\left(30-70{ }^{\circ} \mathrm{C}\right)$ were optimized iteratively (each individually and then again to fine tune). Figure 4 shows that a trithiol, [4], concentration of $10 \mu \mathrm{M}$ or higher results in greater than $90 \%$ radiochemical yield of $\left[{ }^{77} \mathrm{As}\right] \mathbf{5}$. Figure 5 shows that monothiol concentrations of $10 \mathrm{mM}$ or higher result in greater than $90 \%$ radiochemical yield of $\left[{ }^{77} \mathrm{As}\right] \mathbf{5}$. Figure 6 shows the radiochemical yield of $\left[{ }^{77} \mathrm{As}\right] 5$ as a function of temperature after $30 \mathrm{~min}$ at $10 \mu \mathrm{M} 4$ and $15 \mathrm{mM}$ monothiol. Longer reaction times at lower temperatures or higher temperatures for shorter times resulted in $\geq 90 \%$ radiochemical yield of $\left[{ }^{77} \mathrm{As}\right] 5$. Overall, the reaction is limited by the rate at which the arsenic is reduced. Therefore, better labeling yields were observed at lower temperatures $\left(30-40{ }^{\circ} \mathrm{C}\right)$ if the arsenic had been previously reduced with the monothiol at high temperature $\left(60-70{ }^{\circ} \mathrm{C}\right)$, and subsequently cooled to $30-40{ }^{\circ} \mathrm{C}$ before reaction with the trithiol. A balance between the length of reaction time and quantity of reagents (reducing agent, trithiol chelator, and solvents) depends upon the application, which in this case was minimizing the reaction time necessary (20-30 $\mathrm{min})$ to achieve high radiolabeling yield. The optimal reaction conditions resulting in $>90 \%$ radiochemical yield of $\left[{ }^{77} \mathrm{As}\right] 5$ were determined to be with a monothiol concentration of $25 \mathrm{mM}$, a trithiol, 4, concentration of $15 \mu \mathrm{M}$, and a temperature of 60 ${ }^{\circ} \mathrm{C}$ for $30 \mathrm{~min}$.

\section{Figure 4}




\section{Figure 5}

\section{Figure 6}

In Vitro Stability. The $\left[{ }^{77} \mathrm{As}\right] \mathbf{5}$ was observed to be stable in the reaction medium for several days as determined by periodic radioTLC. No decrease in yield was observed from $90 \%$ over a week. The reaction medium contains about a 550-fold excess of monothiol (mercaptoacetate) to trithiol suggesting the complex should be stable to challenge by thiols present in vivo (e.g., glutathione, cysteine). Stability studies of purified $\left[{ }^{77} \mathrm{As}\right] \mathbf{5}$ have not been performed in saline or to cysteine challenge since it has proven difficult to isolate this particular trithiol, $\mathbf{4}$, from the product. Studies are underway to derivatize the trithiol for conjugation to antibodies and peptides, which will result in aqueous solubility and allow for separation. Previous reports on direct radiolabeling of thiol modified mAbs and nanoparticles with NCA radioarsenic have demonstrated high stability $[16,18,19]$.

\section{Conclusion}

The thiophilic nature of arsenic led us to develop arsenic (III) trithiol chemistry for translation to the NCA ${ }^{72 / 77}$ As radiotracer level. A NCA bicyclic $\left[{ }^{77}\right.$ As]arsenic trithiol was synthesized through the in situ reduction of arsenate to a reactive tris(monothiol)-As(III) intermediate. The high yield and stability of a single $\mathrm{NCA}{ }^{77}$ As trithiol complex indicates this framework is suitable for development of matched pair agents for non-invasive in vivo imaging and radiotherapy of tumors with ${ }^{72,77}$ As. Studies are underway to synthesize a trithiol bifunctional chelate for conjugation to a targeting vector such as a peptide or monoclonal antibody.

\section{Acknowledgments}

The authors gratefully acknowledge support from the US Department of Energy, Office of Science, Isotope Research Program under grants DE-SC0003851 and DE-SC0010283, and trainee support from NIBIB Training Grant 5 T32-EB004822 (AJD). The ${ }^{77}$ As was produced at the University of Missouri Research Reactor Center. The authors thank Drs. Nathan Leigh and Fabio Gallazzi from the University of Missouri Mass Spectrometry Facility for running the ESIMS and LC-ESI-MS analysis, and Dr. Wei Wycoff from the University of Missouri NMR Facility for assistance with NMR studies. 


\section{References}

1. Nayak, T. K.; Brechbiel, M. W. Radioimmunoimaging with Longer-Lived PositronEmitting Radionuclides: Potentials and Challenges. Bioconjugate Chem. 2009; 20: 825841.

2. Wycoff, D. E.; Gott, M. D.; DeGraffenreid, A. J.; Morrow, R. P.; Sisay, N.; Embree, M. F.; Ballard, B.; Fassbender, M. E.; Cutler, C. S.; Ketring, A. R.; Jurisson, S. S., Chromatographic separation of selenium and arsenic: A potential ${ }^{72} \mathrm{Se}^{72}$ As generator. J. Chromatography A 2014; 1340: 109-114.

3. Ballard, B.; M. Nortier, F.; R. Birnbaum, E.; D. John, K.; R. Phillips, D.; E. Fassbender, M., Radioarsenic from a Portable ${ }^{72} \mathrm{Se} /{ }^{72}$ As Generator: A Current Perspective. Current Radiopharmaceuticals 2012; 5(3): 264-270.

4. Jennewein, M.; Qaim, S. M.; Kulkarni, P. V.; Mason, R. P.; Hermanne, A.; Rösch, F., A no-carrier-added ${ }^{72} \mathrm{Se} /{ }^{72} \mathrm{As}$ radionuclide generator based on solid phase extraction. In Radiochim. Acta 2005; 93: 579-583.

5. Chajduk, E.; Doner, K.; Polkowska-Motrenko, H.; Bilewicz, A. Novel radiochemical separation of arsenic from selenium for ${ }^{72} \mathrm{Se}^{72} \mathrm{As}$ generator. Appl. Radiat. Isot. 2012; 70: 819-822.

6. Phillips, D. R. Production of Selenium-72 and Arsenic-72. United States Patent 5,371,372; 1994.

7. Jahn, M.; Radchenko, V.; Filosofov, D.; Hauser, H.; Eisenhut, M.; Rösch, F.; Jennewein, M. Separation and purification of no-carrier-added arsenic from bulk amounts of germanium for use in radiopharmaceutical labeling. Radiochim. Acta 2010; 98: 807-812.

8. Jennewein, M.; Lewis, M. A.; Zhao, D.; Tsyganov, E.; Slavine, N.; He, J.; Watkins, L.; Kodibagkar, V. D.; O'Kelly, S.; Kulkarni, P.; Antich, P. P.; Hermanne, A.; Rosch, F.; Mason, R. P.; Thorpe, P. E. Vascular imaging of solid tumors in rats with a radioactive arsenic-labeled antibody that binds exposed phosphatidylserine. Clin. Cancer Res. 2008; 14: 1377-85.

9. Bokhari, T. H.; Ahmad, M.; Khan, I. U. Separation of no-carrier-added arsenic-77 from neutron irradiated germanium. Radiochim. Acta 2009; 97: 503-506.

10. Chattopadhyay, S.; Pal, S.; Vimalnath, K. V.; Das, M. K. A versatile technique for radiochemical separation of medically useful no-carrier-added (nca) radioarsenic from irradiated germanium oxide targets. Appl. Radiat. Isot. 2007; 65: 1202-1207.

11. Shehata, M. M.; Scholten, B.; Spahn, I.; Coenen, H. H.; Qaim, S. M. Separation of radioarsenic from irradiated germanium oxide targets for the production of ${ }^{71} \mathrm{As}$ and ${ }^{72} \mathrm{As}$. J. Radioanal. Nucl. Chem. 2011; 287: 435-442.

12. Jennewein, M.; Qaim, S. M.; Hermanne, A.; Jahn, M.; Tsyganov, E.; Slavine, N.; Seliounine, S.; Antich, P. A.; Kulkarni, P. V.; Thorpe, P. E.; Mason, R. P.; Rosch, F. A new method for radiochemical separation of arsenic from irradiated germanium oxide. Appl. Radiat. Isot. 2005; 63: 343-351. 
13. Maki, Y.; Murakami, Y., The separation of arsenic-77 in a carrier-free state from the parent nuclide germanium-77 by a thin-layer chromatographic method. J. Radioanal. Chem. 1974; 22: 5-12.

14. National Nuclear Data Center: http://www.nndc.bnl.gov.

15. Andersen, O. Principles and Recent Developments in Chelation Treatment of Metal Intoxication. Chem. Rev. 1999; 99: 2683-2710.

16. Herth, M. M.; Barz, M.; Jahn, M.; Zentel, R.; Roesch, F. ${ }^{72 / 74}$ As-labeling of HMPA based polymers for long-term in vivo PET imaging. Bioorg. Med. Chem. Lett. 2010; 20: 54545458.

17. Kitchin, K. T.; Wallace, K. Arsenite binding to synthetic peptides based on the Zn finger region and the estrogen binding region of the human estrogen receptor- $\alpha$. Toxicol. Appl. Pharmacol. 2005; 206: 66-72.

18. Jennewein, M.; Hermanne, A.; Mason, R. P.; Thorpe, P. E.; Roesch, F. A new method for the labelling of proteins with radioactive arsenic isotopes. Nucl. Instrum. Meth. Phys. Res. A 2006; 569: 512-517.

19. Jennewein, M.; Lewis, M. A.; Zhao, D.; Tsyganov, E.; Slavine, N.; He, J.; Watkins, L.; Kodibagkar, V. D.; O’Kelly, S.; Kulkarni, P.; Antich, P. P.; Hermanne, A.; Roesch, F.; Mason, R. P.; Thorpe, P. E. Vascular Imaging of Solid Tumors in Rats with Radioactive Arsenic-Labeled Antibody that Binds Exposed Phosphatidylserine. Clin. Cancer Res. 2008; 14: 1377-1385.

20. Sheldrick, G. A short history of SHELX. Acta Crystallographica Section A 2008; 64: 112-122.

21. Sheldrick, G. SADABS. University of Göttingen, Germany, 1996.

22. Camerano, J. A.; Casado, M. A.; Ciriano, M. A.; Lahoz, F. J.; Oro, L. A. A Trithiol Protio-Ligand and Its Fixation to the Periphery of a Carbosilane Dendrimer as Scaffolds for Polynuclear Rhodium and Iridium Complexes and Metallodendrimers. Organometallics 2005; 24: 5147-5156.

23. Ustabas, R.; Sancak, K.; Er, M.; Unver, Y.; Coruh, U.; Vazquez-Lopez, E. M.; Yavuz, M. Ethene-1,1,2,2-tetrayltetramethylene tetrathiocyanate. Acta Cryst. Sect. E 2005; 61: 3529-3531.

24. Konnert, J. H.; Britton, D. The crystal and molecular structure of methylene dithiocyanate. Acta Cryst. Sect. B 1971; 27: 781-786.

25. Bringeland, R.; Foss, O. The Crystal and Molecular Structure of Ethylene Thiocyanate. Acta Chem. Scand. 1958; 12: 79-88.

26. von Döllen, A.; Strasdeit, H. Models for the Inhibition of Dithiol-Containing Enzymes by Organoarsenic Compounds: Synthetic Routes and the Structure of [PhAs $\left.\left(\mathrm{HlipS}_{2}\right)\right]$ (HlipS ${ }_{2}{ }^{2-}=$ Reduced Lipoic Acid). Eur. J. Inorg. Chem. 1998; 1998: 61-66.

27. Shaikh, T. A.; Bakus, R. C.; Parkin, S.; Atwood, D. A. Structural characteristics of 2halo-1,3,2-dithiarsenic compounds and tris-(pentafluorophenylthio)-arsen. J. Organomet. Chem. 2006; 691: 1825-1833. 
28. Shaikh, T. A.; Parkin, S.; Atwood, D. A. Synthesis and characterization of a rare arsenic trithiolate with an organic disulfide linkage and 2-chloro-benzo-1,3,2-dithiastibole. J. Organomet. Chem. 2006; 691: 4167-4171. 
Table 1. Nuclear properties of ${ }^{72}$ As and ${ }^{77}$ As. [14]

\begin{tabular}{|c|c|c|c|c|}
\hline Isotope & Half-life (h) & Decay Mode (\%) & $\mathbf{E}_{\boldsymbol{\beta m a x}}(\mathbf{M e V})$ & $\mathbf{E}_{\boldsymbol{\gamma}}$ in keV (\%) \\
\hline${ }^{72} \mathbf{A s}$ & 26.0 & $\mathrm{EC}(12), \beta^{+}(88)$ & 2.49 & $511(176), 834(81)$ \\
\hline${ }^{77} \mathbf{A s}$ & 38.8 & $\beta^{-}(100)$ & 0.683 & $239(1.65)$ \\
\hline
\end{tabular}

Table 2. ${ }^{1} \mathrm{H}$ - and ${ }^{13} \mathrm{C}$-NMR data for 2-ethyl-2-(mercaptomethyl)propane-1,3-dithiol (4) and 4ethyl-2,6,7-trithia-1-arsabicyclo[2.2.2]octane (5).

\begin{tabular}{|c|c|c|c|c|c|c|c|}
\hline \multicolumn{4}{|c|}{$\mathbf{4}$} & \multicolumn{4}{|c|}{$\mathbf{5}$} \\
\hline proton & $\boldsymbol{\rho}$ (ppm) & carbon & $\boldsymbol{\rho}(\mathbf{p p m})$ & proton & $\boldsymbol{\rho}(\mathbf{p p m})$ & carbon & $\boldsymbol{\rho}(\mathbf{p p m})$ \\
\hline $\mathrm{CH}_{\mathbf{3}}$ & 0.82 & $\mathbf{C H}_{3}$ & 7.85 & $\mathrm{CH}_{\mathbf{3}}$ & 0.89 & $\mathbf{C H}_{3}$ & 8.17 \\
\hline $\mathrm{SH}$ & 1.18 & $\mathrm{CCH}_{2}$ & 25.10 & & & $\mathrm{CCH}_{2}$ & 37.39 \\
\hline $\mathrm{CCH}_{\mathbf{2}}$ & 1.46 & $\mathrm{SCH}_{2}$ & 28.80 & $\mathrm{CCH}_{2}$ & 1.39 & $\mathrm{SCH}_{2}$ & 31.65 \\
\hline $\mathrm{SCH}_{\mathbf{2}}$ & 2.58 & $\mathbf{C}$ & 41.66 & $\mathrm{SCH}_{2}$ & 2.94 & $\mathbf{C}$ & 31.29 \\
\hline
\end{tabular}


Table 3. X-ray crystal Data, data collection parameters, and refinement parameters for $\mathbf{3}$ and $\mathbf{5}$.

\begin{tabular}{|c|c|c|}
\hline & $\begin{array}{c}\text { Trithiocyanate } \\
\text { (3) }\end{array}$ & $\begin{array}{c}\text { Arsenic Trithiol } \\
\text { (5) }\end{array}$ \\
\hline CCDC \# & 1413544 & 1413545 \\
\hline Formula & $\mathrm{C}_{9} \mathrm{H}_{11} \mathrm{~N}_{3} \mathrm{~S}_{3}$ & $\mathrm{C}_{6} \mathrm{H}_{11} \mathrm{AsS}_{3}$ \\
\hline F.W. & 257.39 & 254.27 \\
\hline Crystal System & Orthorhombic & Monoclinic \\
\hline Space Group & P n a 21 & $\mathrm{P} 21 / \mathrm{c}$ \\
\hline $\mathrm{a}(\AA)$ & $17.766(5)$ & $11.153(3)$ \\
\hline $\mathrm{b}(\AA)$ & $9.957(3)$ & $11.486(3)$ \\
\hline $\mathrm{c}(\AA)$ & $6.913(2)$ & $7.2810(2)$ \\
\hline$\alpha\left(^{\circ}\right)$ & 90.00 & 90.00 \\
\hline$\beta\left(^{\circ}\right)$ & 90.00 & $100.610(3)$ \\
\hline$\gamma\left({ }^{\circ}\right)$ & 90.00 & 90.00 \\
\hline $\mathrm{V}\left(\AA^{3}\right)$ & $1222.8(6)$ & $916.8(4)$ \\
\hline $\mathrm{Z}$ & 4.00 & 6.00 \\
\hline $\mathrm{r}_{\text {calc, }} \mathrm{g} / \mathrm{cm}^{3}$ & 1.40 & 1.86 \\
\hline $\mathrm{T}, \mathrm{K}$ & $173(2)$ & $173(2)$ \\
\hline$\mu, \mathrm{mm}^{-1}$ & 0.58 & 4.10 \\
\hline$\lambda \mathrm{source}^{-}(\AA)$ & 0.71 & 0.71 \\
\hline $\mathrm{R}(\mathrm{F})$ & 0.02 & 0.02 \\
\hline $\mathrm{R}_{\mathrm{w}}(\mathrm{F})^{2}$ & 0.06 & 0.05 \\
\hline $\mathrm{GoF}$ & 1.07 & 1.03 \\
\hline
\end{tabular}

$\mathrm{R}=\left(\Sigma|| \mathrm{F}_{\mathrm{O}}|-| \mathrm{F}_{\mathrm{C}}|| / \Sigma\left|\mathrm{F}_{\mathrm{O}}\right| \mid\right) . \mathrm{R}_{\mathrm{W}}=\left[\Sigma \varpi\left(\left|\mathrm{F}_{\mathrm{O}}{ }^{2}\right|-\left|\mathrm{F}_{\mathrm{C}}{ }^{2}\right|\right)^{2} / \Sigma \varpi\left(\left|\mathrm{F}_{\mathrm{O}}{ }^{2}\right|^{2}\right]^{1 / 2}\right.$. 
Table 4. Selected bond angles $\left({ }^{\circ}\right)$ and distances $(\AA)$ for $\mathbf{3}$ and $\mathbf{5}$.

\begin{tabular}{|c|c|c|c|}
\hline \multicolumn{2}{|c|}{ Trithiocyanate (3) } & \multicolumn{2}{c|}{ Arsenic Trithiol (5) } \\
\hline & & & \\
\hline $\mathrm{S}(1)-\mathrm{C}(4)$ & $1.8317(2)$ & $\mathrm{As}(1)-\mathrm{S}(1)$ & $2.2364(8)$ \\
\hline $\mathrm{S}(1)-\mathrm{C}(7)$ & $1.6932(2)$ & $\mathrm{As}(1)-\mathrm{S}(2)$ & $2.2379(8)$ \\
\hline $\mathrm{S}(2)-\mathrm{C}(5)$ & $1.8332(1)$ & $\mathrm{As}(1)-\mathrm{S}(3)$ & $2.2348(7)$ \\
\hline $\mathrm{S}(2)-\mathrm{C}(8)$ & $1.6977(2)$ & & \\
\hline $\mathrm{S}(3)-\mathrm{C}(6)$ & $1.8289(1)$ & & \\
\hline $\mathrm{S}(3)-\mathrm{C}(9)$ & $1.6935(2)$ & & \\
\hline $\mathrm{N}(1)-\mathrm{C}(7)$ & $1.1468(2)$ & & \\
\hline $\mathrm{N}(2)-\mathrm{C}(8)$ & $1.147(2)$ & & \\
\hline $\mathrm{N}(3)-\mathrm{C}(9)$ & $1.145(2)$ & & \\
\hline & & & $97.00(2)$ \\
\hline $\mathrm{N}(1)-\mathrm{C}(7)-\mathrm{S}(1)$ & $179.19(2)$ & $\mathrm{S}(1)-\mathrm{As}(1)-\mathrm{S}(2)$ & $96.79(2)$ \\
\hline $\mathrm{N}(2)-\mathrm{C}(8)-\mathrm{S}(2)$ & $177.80(1)$ & $\mathrm{S}(3)-\mathrm{As}(1)-\mathrm{S}(1)$ & $96.82(3)$ \\
\hline $\mathrm{N}(3)-\mathrm{C}(9)-\mathrm{S}(3)$ & $175.87(2)$ & $\mathrm{S}(3)-\mathrm{As}(1)-\mathrm{S}(2)$ & \\
\hline
\end{tabular}




\section{Schemes}

(1)

(2)

(3)
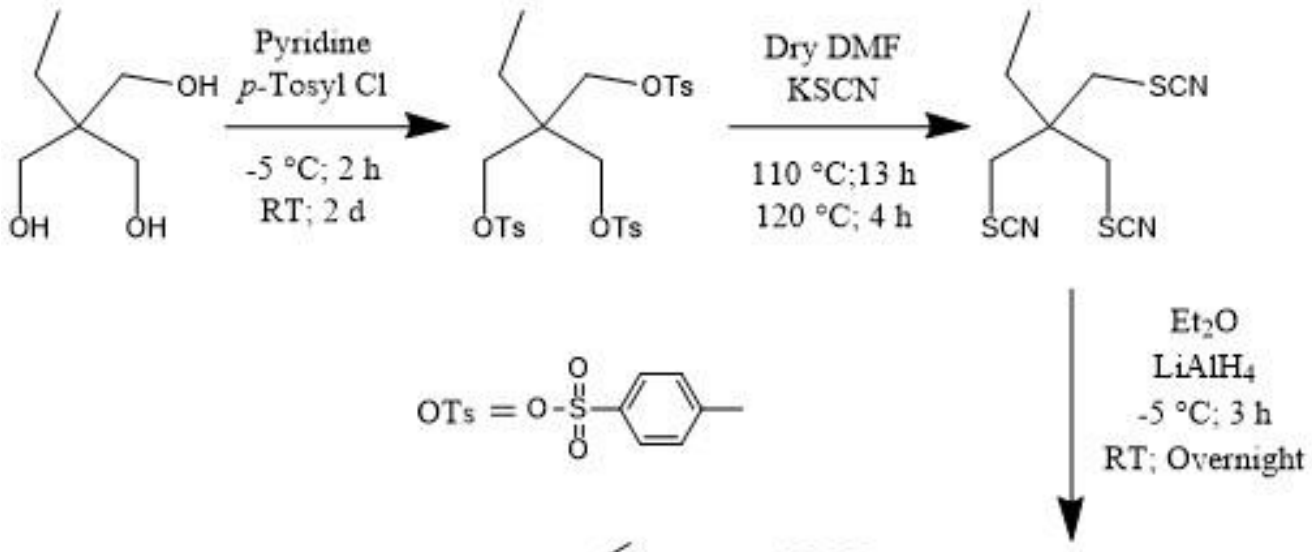

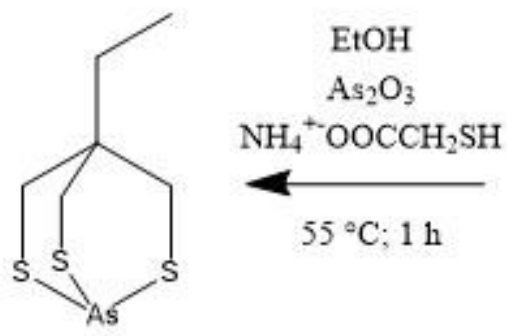

(5)

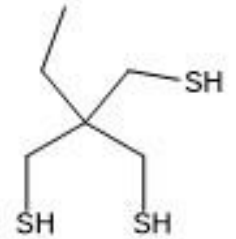

(4)

Scheme 1. Synthesis of 4-ethyl-2,6,7-trithia-1-arsabicyclo[2.2.2]octane, 5. 


\section{List of Figures}

Figure 1. ORTEP representation of 3 (CCDC 1413544) with 50\% probability ellipsoids.

Figure 2. ORTEP representation of (5) (CCDC 1413545) with 50\% probability ellipsoids.

Figure 3. HPLC chromatograms of (a) purified standard of 5 by UV-Vis detection $\left(\mathrm{t}_{\mathrm{r}} 9.75 \mathrm{~min}\right)$, and (b) $\left[{ }^{77} \mathrm{As}\right] 5$ by radiodetection $\left(\mathrm{t}_{\mathrm{r}} 9.88 \mathrm{~min}\right)$.

Figure 4. The radiochemical yield of $\left[{ }^{77} \mathrm{As}\right] 5$ with varying trithiol $(4)$ concentrations $(\mathrm{n}=3)$ at $10 \mathrm{~min}, 25 \mathrm{mM}$ monothiol and $60{ }^{\circ} \mathrm{C}$.

Figure 5. Optimization of the radiochemical yield of $\left[{ }^{77} \mathrm{As}\right] \mathbf{5}$ with varying monothiol concentration $(\mathrm{n}=3)$ at 20 and $30 \mathrm{~min}, 10 \mu \mathrm{M}$ trithiol $(4)$ and $60{ }^{\circ} \mathrm{C}$.

Figure 6. Optimization of the radiochemical yield of $\left[{ }^{77} \mathrm{As}\right] \mathbf{5}$ at various temperatures after 30 min with $10 \mu \mathrm{M}$ trithiol, 4 , and $15 \mathrm{mM}$ ammonium mercaptoacetate $(\mathrm{n}=3)$. 


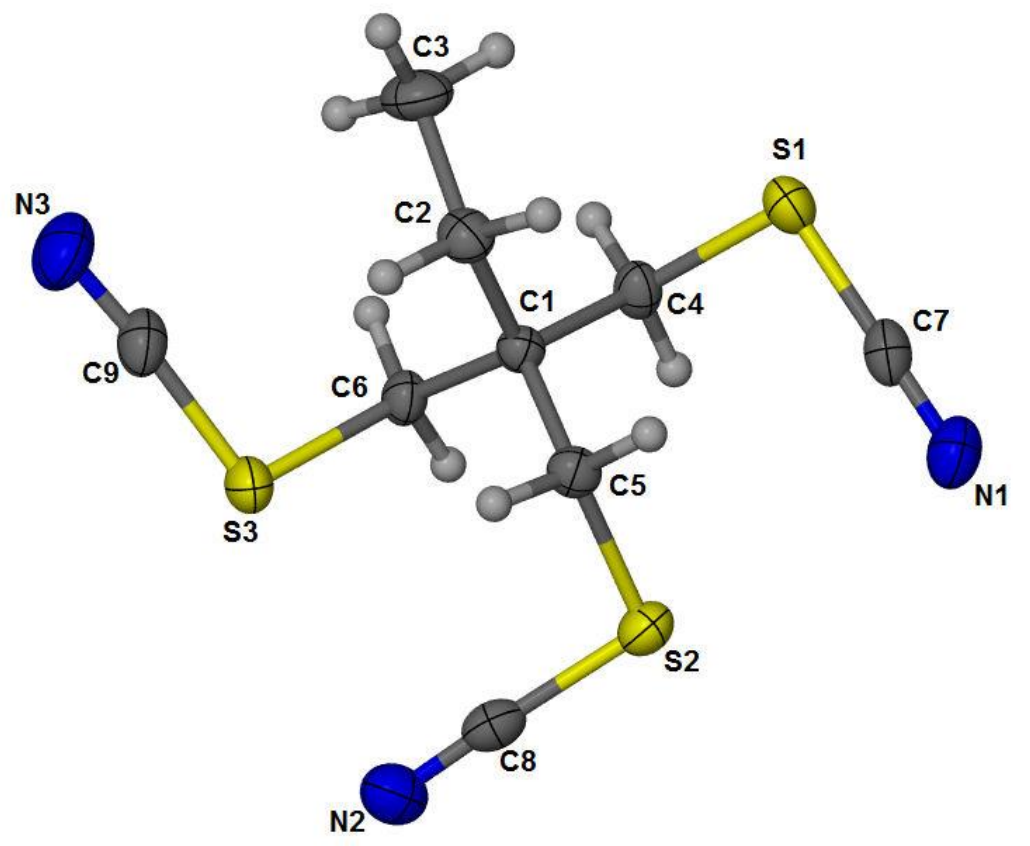

Figure 1. ORTEP representation of (3) (CCDC 1413544) with 50\% probability ellipsoids.

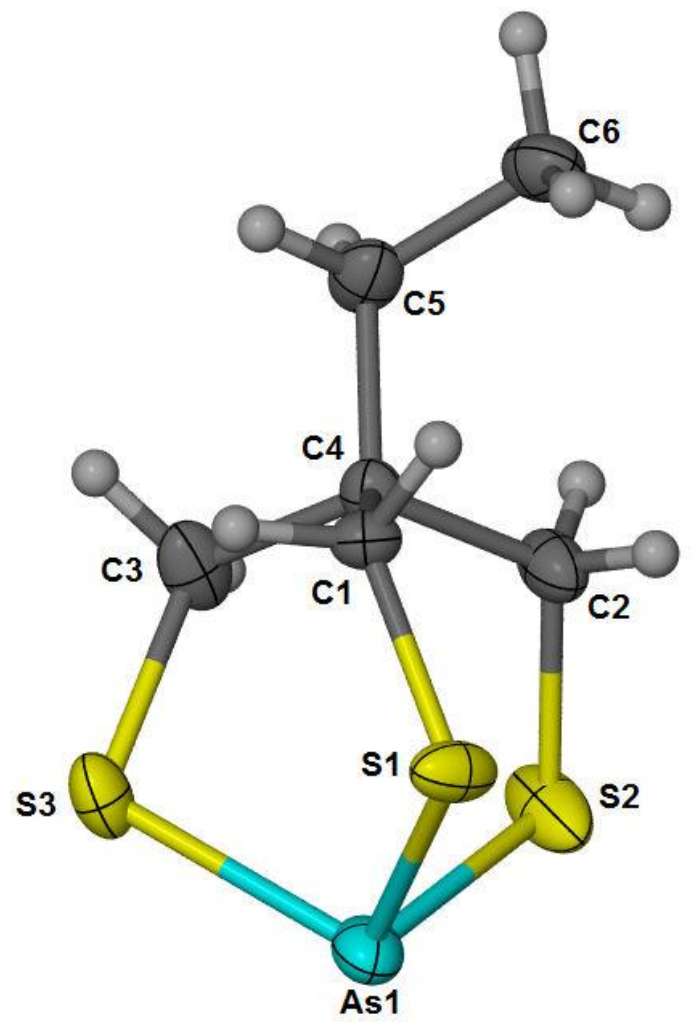

Figure 2. ORTEP representation of (5) (CCDC 1413545) with 50\% probability ellipsoids. 

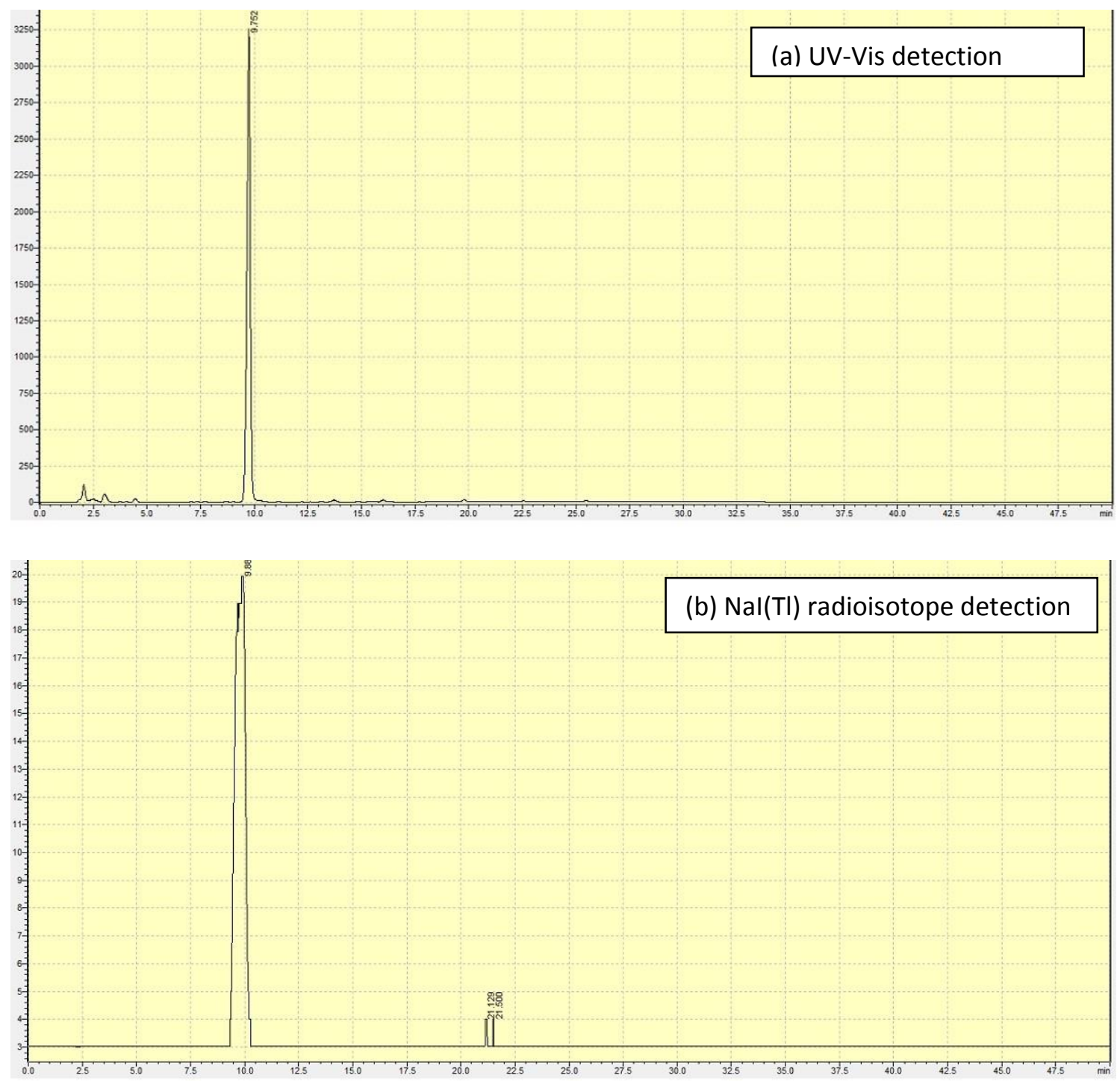

Figure 3. HPLC chromatograms of (a) purified standard of 5 by UV-Vis detection $\left(\mathrm{t}_{\mathrm{r}} 9.75 \mathrm{~min}\right)$, and (b) $\left[{ }^{77} \mathrm{As}\right] 5$ by radiodetection $\left(\mathrm{t}_{\mathrm{r}} 9.88 \mathrm{~min}\right)$. 


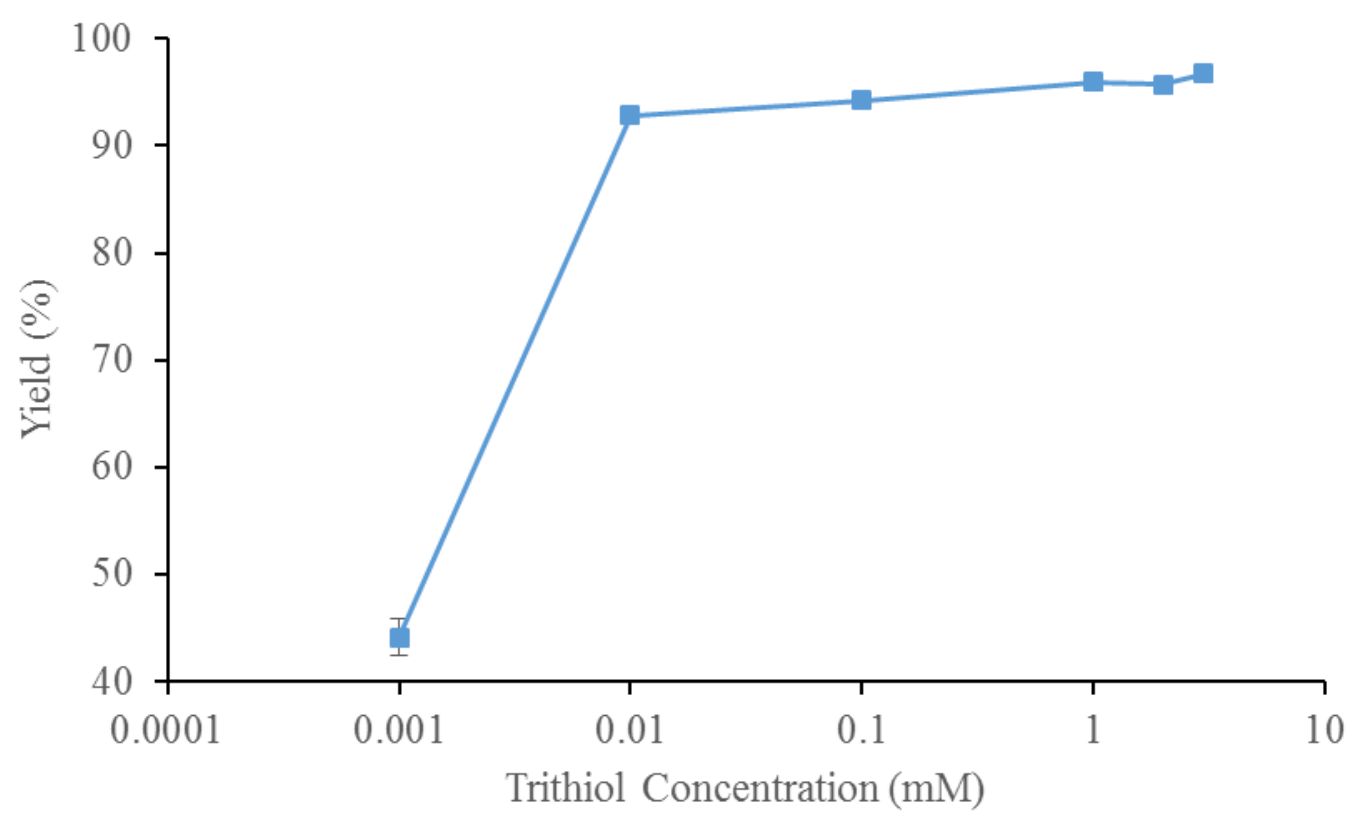

Figure 4. Optimization of the radiochemical yield of $\left[{ }^{77} \mathrm{As}\right] \mathbf{5}$ with varying trithiol (4) concentrations $(\mathrm{n}=3)$ at $10 \mathrm{~min}, 25 \mathrm{mM}$ monothiol and $60{ }^{\circ} \mathrm{C}$.

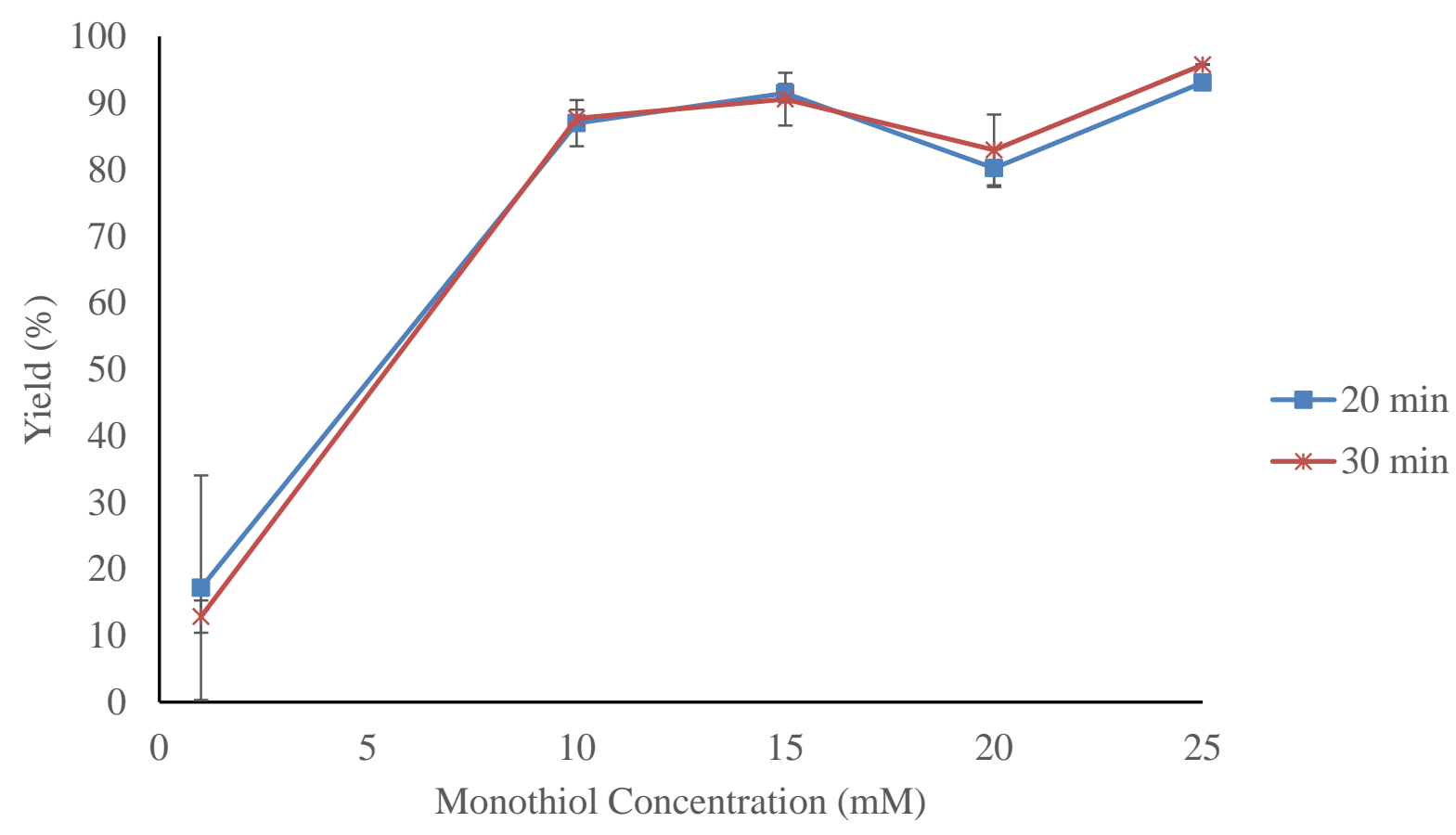

Figure 5. Optimization of the radiochemical yield of $\left[{ }^{77} \mathrm{As}\right] \mathbf{5}$ with varying monothiol concentration $(\mathrm{n}=3)$ at 20 and $30 \mathrm{~min}, 10 \mu \mathrm{M}$ trithiol $(4)$ and $60{ }^{\circ} \mathrm{C}$. 


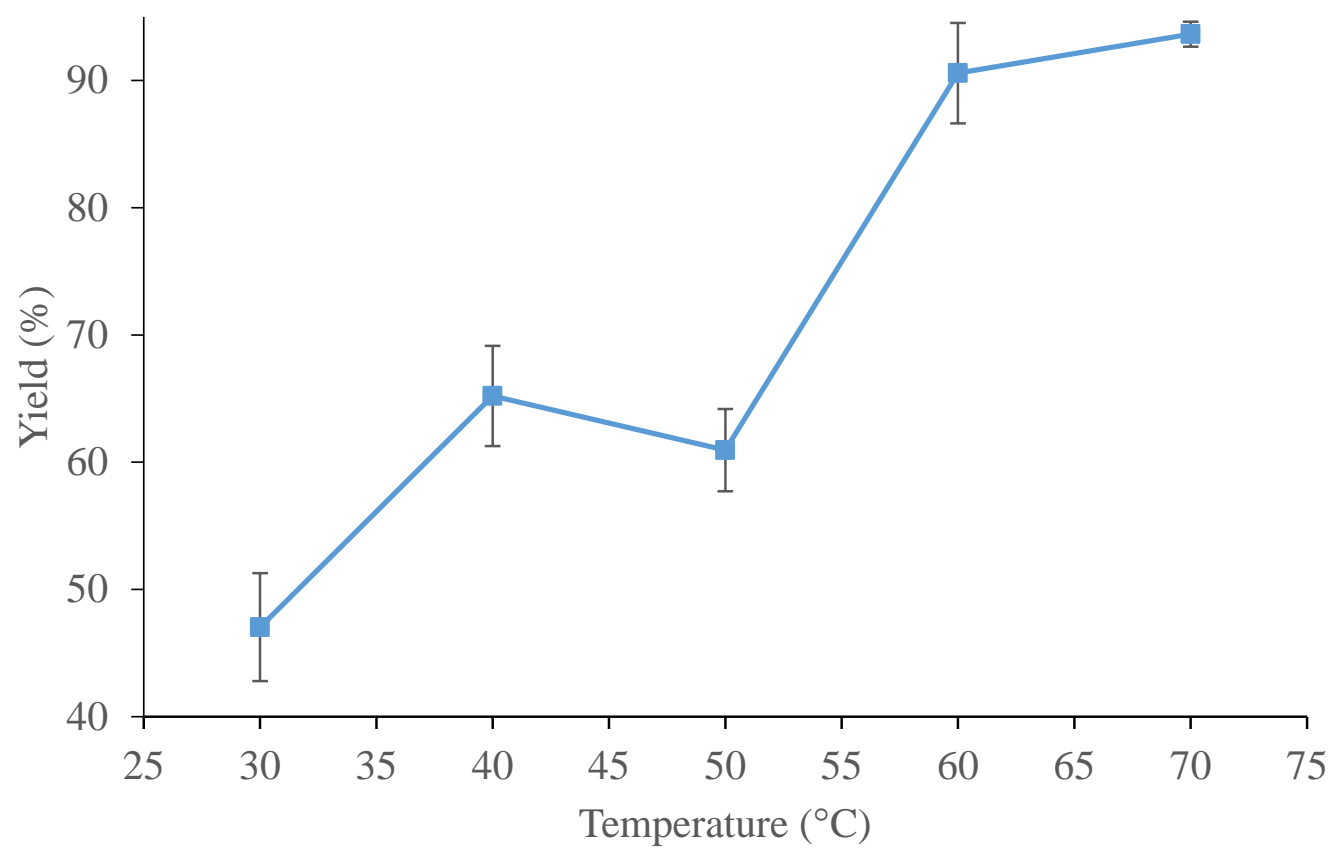

Figure 6. Optimization of the radiochemical yield of $\left[{ }^{77} \mathrm{As}\right] \mathbf{5}$ at various temperatures after 30 min with $10 \mu \mathrm{M}$ trithiol (4) and $15 \mathrm{mM}$ monothiol $(\mathrm{n}=3)$. 